\title{
Mental Rigidity as a Predictor of the Results of the Matches of Sabre Players under Thirteen Years Old in the Arab Republic of Egypt
}

"Dr/ Rasha Rabea Fahmy Ali Al-dien

Introduction \& Research Problem

The more concern for psychology in the sportive field is not all out of a sudden, but because of its close relationship with sportive training science, the physiology of sport and more for making use of its theories and their application, thus improving the sportsman's performance in the training process and sportive competitions.

Consequently, Osama Rateb (2001) sees that excellence in sport depends on the extent of the players' benefit from their psychological abilities in a way that is not less than their physical abilities; since psychological abilities help people to charge their physical power to make the maximum and best sportive performance $(3: 6)$.

Additionally, Jolly Ray \& Simon Middleton et al (2003)

confirm that mental rigidness is the highest psychological level we can reach, what requires a new technique and mental skills to provide sportsmen with stamina compared to their competitors during training and competition through improving concentration, confidence and stability under pressures : $1 \varepsilon$ ) $(Y \cdot 9:$ iv $)(9$.

Osama Abdurrahman (2003), Ibrahim Nabil (2005) and Hussein Hagag \& Ramzy Abdulkader (2007) see that the nature of performance in Sabreplay depends on two opposing players while they share the performance of defense and attack skills of Sabreplay in a hit and run fashion in order for one of them can precede the other to get a legal touch. It is also characterized by dynamicity since performance does not go monotonously according to the Sabre players' reactions

"A lecturer of sportive training (swordplay) in the Department of Sportive Training and Movement Science, Faculty of Physical Education, Assiut Uniyersity

$$
\text { Assiut Journal For Sport Science Arts }
$$


(responses). Movements change based on battling situations and how they change; performance gets speed in different attack situations while the performance speed rate decreases in other situations such as readiness for attack or thinking of preparing attacks. This is because such situations require special abilities, skills and patterns of movement according to the nature and style of performance : !) ( $\Gamma^{\Gamma}:$ ). $\left(\vee \Lambda_{-} \vee \vee \vee \vee \vee\left(\Sigma \Lambda_{-} \leqslant \tau\right.\right.$

In this connection, the stresses imposed by the nature of performance in Sabreplay are clarified, such a nature that affects players' performance level during training and competition. Social pressures represented by parents, family, coaches and players a big role in maximizing psychological pressures on the player. All such parties encourage the player to win, what in turn increases mental pressures on the player because of their fear of failure during competition.

$$
\text { Both Mohamed }
$$

Shamoan \& Magda Ismail (2002) agree on that mental pressures are the element that affects performance most since negative thought and such disturbing thoughts as fear of failure and fear of injury. Such fears affect the mind, resulting in the increase of physiological and physical excitement. Accordingly, the low ability to make decisions negatively affects performance $-191: 9$ ) (Y...

The idea of the current research is manifested through the researcher's theoretical and practical experience and watching and observing some official championships of Sabre players. The researcher found that although preparation methods are somewhat similar, and the performance level of competitive teams in those competitions being approximant in general and in respect of lower age stages which are most affected by competition pressures because of low experience and interaction, many players do not have the ability to face and handle all types of physical, mental and emotional pressures to be more competitive.

This is evident through players' talk too much with the referee, or through their much complain, objection, tension and lack of concentration. Gould et al (2002) agree that as a result of the player being 
affected by surrounding conditions such as the climate, referee and spectacles, and through the identification and tracking such behaviors, we can identify how are players and team mentally rigid :11) ( $($ q $)$.

The researcher observed through reviewing available references and practical studies that no study has tackled mental rigidness as a predictor of the results of Sabreplay matches. Many specialists in the training filed also agreed on the significance of mental rigidness; Gould et al (2002) indicates in this regards that mental rigidness is the most important factor in making a sportive achievement (293: 11).

Although specialists in Sabreplay always tried to search for the optimal methods and different techniques capable of achieving physical stability and skill balance of players so that they can exert their maximum effort to continue training to achieve triumph and eminence. Nevertheless, such balance cannot be achieved with no care about the mental aspect since in order for making a sportive achievement we need to focus on the mental side during sportive training and competition in general and during Sabreplay in specific for achieving the balance in the preparation of players. Thus, the researcher used Jimes Loehr scale (1994) for Sabre players under 13 years old to determine the ratios of participation of mental rigidity dimensions in the results of matches and the level of players' mental rigidity. The researcher also used it to identify the relation between mental rigidity presented in the results of matches and identifying if there are differences in mental rigidity according to players' levels based on the results of matches (high-moderate-low) to be able to predict the results of matches. This is what directs the researcher to do this research on mental rigidity as a predictor of the results of matches of Sabre players under 13 years old in Egypt.

\section{Research objectives}

Through using Jimes Loehr scale of mental rigidity (1994) on Sabre players under 13 years old in the national championship, the following has been identified:

1- the participation ratios of mental rigidity dimensions in 
the matches of Sabre players under 13 years old, 2- the level of under-thirteenyear-old Sabre players' mental rigidity,

3- the correlation between mental rigidity and the results of under-thirteen-year-old Sabre players' matches, and 4- the existence of a statistically significant difference in mental rigidity among the players according to their levels based on match results (high-moderate-low) of the sample under study.

\section{Research questions}

1-What are the levels of participation of mental rigidity along with its dimensions in under-thirteen-year-old Sabre players' match results?

2- What is the level of underthirteen-year-old Sabre players' mental rigidity?

3- What is the correlation between mental rigidity and under-thirteen-year-old Sabre players' match results?

4- Are there statistically significant differences among the players according to their levels based on match results (high-moderate-low) of the sample under study?

\section{Research terms}

Mental rigidity: It is the ability to maintain ideal performance when training or sportive competition stressors get maximized ( $(\cdot 9: 1 \vee)$.

\section{Research methodology}

Method: the researcher used descriptive method for it is relevant to the nature of the study.

Population: the population encompassed under-thirteenyear-old Sabre players.

Sample:

The sample encompassed 17 Sabre players who were chosen purposefully from the national championship for under-thirteen-year-old Sabre players in 2016 which is held in specified halls in Cairo Stadium. The pilot study was conducted on 5 players of AlMaadi Club of the same sample group, but such players will be secluded from this championship because their ages will be above this age category in the championship time. They will be also secluded from the main treatment, thus the number of the main sample participating in this championship will be 12 players. Then, the researcher made the sample homogenous based on the following variables as illustrated in tables $1 \& 2$. 
Table (1)

Mean, standard deviation and Kolmogorov \& Smirnoff Test in the main variables under study $(n=12)$

\begin{tabular}{|c|c|c|c|c|c|}
\hline \multirow[b]{2}{*}{ Z } & \multirow{2}{*}{$\begin{array}{c}\text { Measure } \\
\text { ment } \\
\text { unit }\end{array}$} & \multirow{2}{*}{$\begin{array}{l}3 \\
\stackrel{3}{3}\end{array}$} & \multirow{2}{*}{ 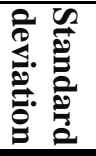 } & \multicolumn{2}{|c|}{ Kolmogorov \& Smirnoff Test } \\
\hline & & & & $\begin{array}{c}\text { Statistical } \\
\text { Power }\end{array}$ & $\begin{array}{c}\text { Significance } \\
\text { level }\end{array}$ \\
\hline 1 & $\mathrm{~cm}$. & 101.01 & $r . r$ & .91 &. .19 \\
\hline 2 & Kg. & $\varepsilon r . r T$ & $\sum . \mu$ & $1 . \cdots$ & $\cdot r V$ \\
\hline 3 & Year & IT.rt & $\cdot .49$ & .74 & $\cdot . \wedge \mu$ \\
\hline 4 & Year & $r .0 \Lambda$ & $\because \vee 9$ & .91 &. .19 \\
\hline $\begin{array}{l}\text { table } \\
\text { Smir } \\
\text { that } \\
\text { distr } \\
\text { varia }\end{array}$ & $\begin{array}{l}\text { It is ev } \\
\text { (1) that } K \\
\text { off Test } \\
\text { e sample } \\
\text { ution in } \\
\text { les under }\end{array}$ & $\begin{array}{l}\text { ent thi } \\
\text { Imogor } \\
\text { ues inc } \\
\text { lows nc } \\
\text { the }\end{array}$ & $\begin{array}{l}\text { gh } \\
\& \\
\text { ate } \\
\text { hal } \\
\text { ain }\end{array}$ & $\begin{array}{l}\text { such val } \\
(1 . \cdots: \cdot .7 \\
\text { levels tha } \\
(\cdot \wedge \text { rwhic } \\
0>05 \text {, wh } \\
\text { follow no }\end{array}$ & $\begin{array}{l}\text { ranged from } \\
\text { ith significance } \\
\text { lged from }: \cdot r v) \\
\text { are higher than } \\
\text { ndicates that they } \\
\text { l distribution. }\end{array}$ \\
\hline
\end{tabular}

Table (2)

Mean, standard deviation and Kolmogorov \& Smirnoff Test in the physical tests under study $(n=12)$

\begin{tabular}{|c|c|c|c|c|c|c|}
\hline \multirow{2}{*}{ Z } & \multirow{2}{*}{$\begin{array}{c}\text { Variables } \\
\text { Tests }\end{array}$} & \multirow{2}{*}{ 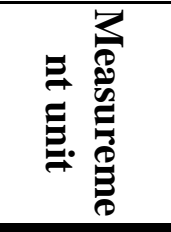 } & \multirow{2}{*}{ : } & \multirow{2}{*}{ 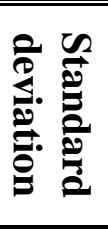 } & \multicolumn{2}{|c|}{$\begin{array}{l}\text { Kolmogorov \& } \\
\text { Smirnoff Test }\end{array}$} \\
\hline & & & & & $\begin{array}{l}\text { Statistical } \\
\text { Power }\end{array}$ & $\begin{array}{c}\text { Significance } \\
\text { level }\end{array}$ \\
\hline 1 & $\begin{array}{l}\text { Speed of forward } \\
\text { movement for } 41 \\
\text { m. }\end{array}$ & $\mathrm{T}$ & ๆ. $\varepsilon$ & $\because v \cdot$ & .09 & $\cdot \wedge \vee$ \\
\hline 2 & $\begin{array}{l}\text { Speed of moving } \\
\text { backward for } 41 \\
\text { m. }\end{array}$ & $\mathrm{T}$ & 7.1 & $\because \wedge 7$ &.$V r$ & .70 \\
\hline 3 & $\begin{array}{ll}\text { Taking } & \text { over } \\
\text { speed } & \end{array}$ & Number & V.Ar & 1.11 & $\because \vee \wedge$ & $\because .0 \mathrm{~V}$ \\
\hline $\begin{array}{l}\text { res } \\
\text { val } \\
\text { Sm } \\
\text { san } \\
\text { dis }\end{array}$ & $\begin{array}{l}\text { It is evident } \\
\text { Its of table } \\
\text { es of Kolm } \\
\text { rnoff Test indic } \\
\text { ple follow } \\
\text { ibution in th }\end{array}$ & $\begin{array}{l}\text { through th } \\
\text { 2) that th } \\
\text { ogorov } \\
\text { ate that th } \\
\text { norms } \\
\text { e physica }\end{array}$ & & \multicolumn{3}{|c|}{$\begin{array}{l}\text { variables under study since } \\
\text { such values ranged from }: \cdot . \diamond 9) \\
(\cdot \vee \wedge \text { with significance levels } \\
\text { that ranged from }: \bullet . \diamond \vee) \\
(\bullet \wedge \vee \text { and they are higher than }\end{array}$} \\
\hline
\end{tabular}

Assiut Journal For Sport Science Arts 
0.05 , what indicates that they follow normal distribution.

Materials \& Instruments for Data Collection

1- Devices and instruments used in the research:

The researcher used the following instruments and devices for measuring research variables:

- medical scales to which is attached a restameter for measuring weight for the nearest kilogram and length for the nearest centimeter

- a stopwatch

- a whistle to indicate the start

- legal Sabreplay sit

- fencing Sabre

- sellotape

- pens for marking the scale

\section{2-The used forms:}

- forms for filling out information and measuring variables of growth, training age and physical tests related to the sample homogeneity, appendix no. (1).

- forms for filling out information about emptying the mental rigidity scale for the sample, appendix no. (2).

\section{3-The used tests:}

- A test for measuring performance speed (time for moving forward for $14 \mathrm{~m}$. and time of retreat for $14 \mathrm{~m}$.)
Osama Abdurrahman (1999), appendix no. (3).

- A test for measuring speed of endurance, Osama Abdurrahman (1999) (2), appendix no. (3).

- Psychological performance inventory for identifying mental rigidity, appendix no. (4).

The researcher administered James Loehr's (I r) ( ( $99 \varepsilon)$ psychological performance inventory for identifying mental rigidity after preparation and localization. The inventory contains seven psychological determinants:

1-Self-Confidence

2- Negative Energy

3-Attention Control

4- Visual \& Imagery Control

5-Motivational Level

6- Positive Energy

\section{7-Attitude Control}

The player answers the sentences of the test (scale) on five-rating system scales, and he/she gets five marks when the sentence is applicable; one mark when the sentence is not applicable as in appendix no. (4). The test contains 42 sentences and each determinant of the previously explained seven determinants are represented by 6 sentences, appendix no. (5).

\section{Pilot study}


The researcher conducted a pilot study from Monday, 18/1/2016 to $7 / 2 / 2016$, which has the following objectives:

-Interviewing some players and coaches from some clubs to determine the examinees for calculating scientific coefficients. -Identifying the obstacles that may face the researcher during the administration of the main study.

- Making sure that the sentences are clear for examinees.

- Determination of examinees' response mark on the test.

- Calculating scientific coefficients for (special) physical tests used in the homogeneity of the sample under study.

- Calculating scientific coefficients for the employed scale.

Through the administration of the scale on the pilot study, the researcher identified at last the extent to which the pilot study could understand the sentences of the scale through their answers since there are no sentences that may bear more than one interpretation or they are ambiguous.

- Calculating scientific coefficients for the tests employed in the homogeneity of the sample and the scientific coefficients for the psychological performance inventory to identify mental rigidity.

\section{Research Procedures}

Procedures of the Main Study

After ensuring the validity and reliability of the scale, the main treatment was implemented on the players participating in the national Sabreplay championship under 13 years old in 2016 during the championship. The players participating in that championship was 12 players who represent the main sample. The championship is administered in the halls specified for that purpose in Cairo Stadium on Friday 19/2/2016, appendix no. (5).

\section{Statistical Treatments}

The researcher used the following statistical techniques in processing results:

Mean- standard deviation

- average- Pearson coefficient Man-Whitney test

- Kolmogorov \& Smirnoff test

- multiple correlation- the coefficient of determinationthe fixed amount- F-value $-\mathrm{T}$ value - R-value - regression coefficient- the estimated 
grade - relative weight - the item direction - chi- square

\section{Results \& Discussion}

To achieve the research objectives, and to answer its questions, based on the results that the researcher obtained by means of statistical analysis and using references and studies, the results were presented and discussed.

1-Presenting and discussing the results of the first question entitled "What are the levels of participation of mental rigidity along with its dimensions in under-thirteen-year-old Sabre players' match results?" To answer this question, multiple correlation, the coefficient of determination that represents participation ratios, the fixed value, coefficient of regression, F-value and T-value were calculated. The results of table (3) illustrates that:

\section{Table (3)}

Participation ratios of mental rigidity dimensions in the match results of under-thirteen-year-old Sabre players $(n=12)$

\begin{tabular}{|c|c|c|c|c|c|c|c|c|}
\hline ?ִ & $\begin{array}{l}\text { Kariables } \\
\text { Independent }\end{array}$ & 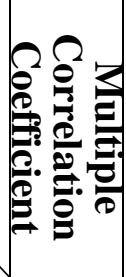 & 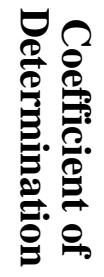 & 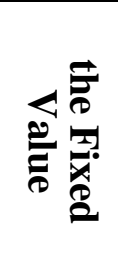 & 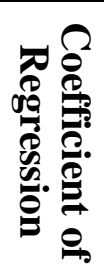 & 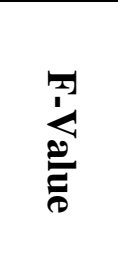 & 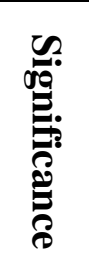 & 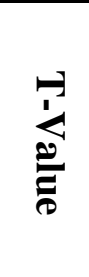 \\
\hline 1 & $\begin{array}{l}\text { Self- } \\
\text { confidence }\end{array}$ & \multirow{8}{*}{$\because .99$} & \multirow{8}{*}{$\cdot .91$} & \multirow{8}{*}{$0 . . \mathrm{V}$} & r.) & \multirow{8}{*}{ ro.ro } & \multirow{8}{*}{$\because \cdots$} & $1 . \wedge$ \\
\hline 2 & Negative energy & & & & $7 . V Y$ & & & 1.70 \\
\hline 3 & Attention control & & & & 7.04 & & & 1.90 \\
\hline 4 & Visual control & & & & $0 . \wedge 1$ & & & $1 . Y_{0}$ \\
\hline 5 & $\begin{array}{l}\text { Motivational } \\
\text { level }\end{array}$ & & & & ـ. & & & .9 . \\
\hline 6 & Positive energy & & & & $0 . \cdot 1$ & & & 1.10 \\
\hline 7 & $\begin{array}{l}\text { Direction } \\
\text { control }\end{array}$ & & & & $1 . r \varepsilon$ & & & .11 \\
\hline \multicolumn{2}{|c|}{ Mental rigidity scale } & & & & 1.17 & & & Y. \\
\hline
\end{tabular}

Table F-value at 0.05 level of significance $=2.20$

It is evident through for 0.98 of the total variation of table no. (3) that mental rigidity scale along with its dimensions altogether account match results (the dependent variable) which is a very big amount of variation that the 
dimensions of the scale and total sum account for. It is also clear that multiple regression analysis results are significant since calculated F-value was 35.35, which is significant at 0.05 level. Additionally, calculated T-value ranged from 1.95:0.18, which are nonsignificant values at 0.05 level. This comes with the exception of mental rigidity scale as a whole where T-value was 2.4 , which is higher than its table value at 0.05 level.

The researcher explains the participation ratios of the dimensions of mental rigidity scale being insignificant as such rations of participation of the seven dimensions of mental rigidity individually are ineffective in match results. The researcher attributes this to the players having different and variant mental rigidity dimensions dependent on the variant clubs to which they belong in the championship, as well as to the variant training programs that the support psychological aspects to which the players are subject to in the clubs.

The researcher also explains the statistical significance between the sum of mental rigidity as a whole in match results as the participation ratios of mental rigidity as a whole without separating the seven dimensions. Participation ratios of mental rigidity scale as a whole was 0.98 .

The researcher sees that this confirms the significance of supporting and developing mental rigidity as a whole with no separation of its dimensions or focusing on a dimension rather than the other during sportive training in all stages of the training season for Sabre players under 13 years.

This explains the clear effect of the variable of mental rigidity dimensions as a whole whereby we may also deduce that the more mental rigid is the player, the better are match results.

The researcher sees that mental rigidity is the ability to maintain ideal performance when training or sportive competition stressors get maximized; this requires a new technique and mental related skills. Furthermore, the performance instability during competition is initially attributed to psychological variables of which the first and foremost are mental rigidity variables. This is what Jolly 
Ray( $(\leqslant)(r \cdots r)$ confirms and adds that mental rigidity is an acquired attribute away from heredity.

In this regard, scientists refer to the significance of improving specific psychological attributes, which in turn contribute to one's ability to overcome special obstacles that are related to a specific sportive activity or those special obstacles related to the individual's trial to attain the highest level in that sportive activity (16).

Presenting and discussing the results of question no. (2), entitled "What is the level of under-thirteenyear-old Sabre players' mental rigidity?" To answer this question, mean, standard deviation and Pearson coefficient were calculated. Table no. (6) clarify that:

Table (4)

The estimated grade, relative weight, mean and the directions of the dimensions of mental rigidity scale for Sabre players under 13 years $(n=12)$

\begin{tabular}{|c|c|c|c|c|c|c|}
\hline No & Dimension & $\begin{array}{l}\text { Estimated } \\
\text { grade }\end{array}$ & $\begin{array}{l}\text { Relative } \\
\text { weight }\end{array}$ & Mean & $\begin{array}{l}\text { Item } \\
\text { direction }\end{array}$ & Order \\
\hline 1 & $\begin{array}{l}\text { Self- } \\
\text { confidence }\end{array}$ & Y97 & AT.rY & $\varepsilon .11$ & Strong & $r$ \\
\hline 2 & $\begin{array}{l}\text { Negative } \\
\text { energy }\end{array}$ & $r \leqslant q$ & 79.18 & $r . \leqslant T$ & Strong & V \\
\hline 3 & $\begin{array}{l}\text { Attention } \\
\text { control }\end{array}$ & YVI & VO. rA & r.vT & Strong & 7 \\
\hline 4 & Visual control & rqr & 1).rq & $\varepsilon \cdot V$ & Strong & 0 \\
\hline 5 & $\begin{array}{l}\text { Motivational } \\
\text { level }\end{array}$ & r. & Aะ. IV & $\varepsilon . Y_{1}$ & Very strong & r \\
\hline 6 & Positive energy & ון. & 17.11 & I. I & Very strong & 1 \\
\hline 7 & $\begin{array}{l}\text { Direction } \\
\text { control }\end{array}$ & rqะ & $11.7 \mathrm{~V}$ & $\varepsilon . \wedge$ & Strong & $\varepsilon$ \\
\hline \multicolumn{2}{|c|}{$\begin{array}{l}\text { Mental rigidity } \\
\text { (the sum) }\end{array}$} & $r .17$ & $\Lambda .$. & $\varepsilon . \cdots$ & \multicolumn{2}{|c|}{ Strong } \\
\hline
\end{tabular}

Through table no. (4), it is evident that the relative weight for the sample's responses on the dimensions of mental rigidity scale for Sabre players under 13 ranged from
(^7.11:79.1 $)$. The relative weight for the sum of dimensions is $80.00 \%$ and the means of the sample's responses for the whole dimension 4.00. Positive

Assiut Journal For Sport Science Arts 
energy dimension ranked first of all dimensions since it was achieved very strongly. The sample's responses on the scale as a whole revealed a strong achievement.

The researcher explains the achievement of positive energy dimension on mental rigidity scale very strongly and being ranked first of all dimensions, meaning that the players have a very good deal of positive energy during competition, thus leading to avoiding negative thoughts responsible for tension. This permits the achievement of optimal psychological energy that helps the player to better charge his/her physical, emotional and mental powers.

The researcher explains

the achievement of motivational level dimension on mental rigidity scale very strongly and being ranked first of all dimensions. This means that the players have a very good deal of psychological motivational level during competition, what helps players increase their ability to encounter various psychological pressures found in a competition to achieve the desired objective which is triumph.
In this regard, Keith Pritchard $(10)(r . r)$ indicates that setting a goal, followed by trying to achieve it with motivation and insistence since the player aims to improve his/her fitness and skill has to train seriously to achieve that goal.

The researcher also
explains the strong achievement of self-confidence dimension on mental rigidity scale along with being ranked third, this means that the players have a good deal of support, self-confidence and making positive performance patterns during competition.

Chris Sellars (199v) ( $)$ )indicate that building selfconfidence is considered of the important psychological attributes that can be improved by training. The coach plays an important role in increasing player's self-confidence through setting goals that the player has to achieve.

The researcher explains the strong achievement of the dimension of direction control on mental rigidity scale along with being ranked fourth, meaning that the players have a good deal of controlling the intensity of their emotions and insistence on achieving 
triumph in sportive competition under whatever pressure.

This is consistent with John Lefkowits et al $(r \ldots r)$ (I))that mental rigidity helps improve various types of emotional control (emotional flexibility, emotional response, emotional strength and emotional healing).

The researcher explains the strong achievement of the dimension of visual control on mental rigidity scale along with being ranked fifth. This means that the players have a good deal of controlling mental thinking for recalling good performance images in their minds to benefit from them in playing situations and in choosing the skills relevant for the specific situation during competition in the championship.

In this connection, Osama Rateb (4) (1990) indicates that the player envisions his/her performance on a specific skill correctly, what is reflected in improving their performance of that motor skill.

The researcher explains the strong achievement of the dimension of attention control on mental rigidity scale along with being ranked sixth of all dimensions. This means that the players have a powerful deal of more concentration and attention, what increases their ability to achieve the best results in a sportive competition.

This result is consistent with what Osama Rateb (6) (2001) indicates as for the significance of improving the player's ability to direct his/her attention towards stimuli related to performance since this permits the attainment of optimal psychological energy.

The researcher also explains that although negative energy dimension has ranked seventh and last, it had a strong level of achievement because of the player's low experience and interaction as a result of their low participation in competitions for their young age compared to elder ages. This may be attributed to players receiving no psychological support by means of coaches and their interest in the physical and skillful aspects.

When negative energy correlates with the player's performance level which is characterized by more emotion looks with a level lower than his/her real abilities, according to Osama Rateb (5) (1997). 
Through calculating the performance of each dimension of mental rigidity according to the players' views, it was possible to calculate their mental rigidity level. This is represented by table (4) that clarifies that the players have a strong level of mental rigidity in the national championship for Sabre players under 13 years.

On this regard, Mohamed Shamoan (8) (2001) indicates that developing mental skills must go in line with developing physical fitness components, and that such skills as attention concentration, mental recall and others have to be planned to be developed just like strength, flexibility and speed. The integration of preparation especially in the first stages has to help develop physical skills along with the mental and emotional. Additionally, neglecting such a preparation hinders achievements on the competitive level.

Presenting and discussing the results of the third question, entitled "What is the correlation between mental rigidity and under-thirteenyear-old Sabre players' match results?" To answer this question, mean, standard deviation and R-value were calculated. Results of table (22) illustrate that:

Table (5)

The correlation between mental rigidity and match results of Sabre players under 13 years $(n=12)$

\begin{tabular}{|c|c|c|c|c|}
\hline No & Variable & Mean & $\begin{array}{l}\text { Standard } \\
\text { deviation }\end{array}$ & $\begin{array}{c}\text { Calculated R- } \\
\text { value }\end{array}$ \\
\hline 1 & Mental rigidity & $171 .$. & TV.s. & \multirow{2}{*}{$\cdot 9 \varepsilon$} \\
\hline 2 & Match results & $\varepsilon Y, Y O$ & $Y 7 . \cdot V$ & \\
\hline
\end{tabular}

R-value at 0.05 level of significance $=0.55$

It is evident through table (5) that there is a positive correlation which is statistically significant between mean scores of mental rigidity and match results of Sabre players under 13 years since calculated R-value was
0.94 which is higher than table R-value at 0.05 level of significance.

The researcher explains that as the more mentally rigid are the Sabre players under 13 years, the higher the match results. Thus, 
the researcher found that there is a correlation between mental rigidity and the match results of the sample under study.

The researcher attributes this to mental rigidity that has psychological skills that represent an important dimension in the preparation of players such as physical, skillful and tactic preparation during training or sportive competition, and it is not less important than them since it plays a basic role in developing performance level as international sportive champions are greatly approximant as for the physical, skillful and tactic levels. The psychological factor determines players' result during competition as it plays a basic role in achieving triumph.
The current research results coincide with what James Loehr (12) (1994) mentioned that mental rigidity contributes to the improvement of players' physical and skillful performance level and that mental skills are related to performance level.

Presenting and discussing the results of the fourth question, entitled "Are there statistically significant differences among the players according to their levels based on match results (highmoderate-low) of the sample under study?" To answer this question, the mean of the ranks and Chi-square were calculated. Results of table (6) illustrates that:

Table (6)

Significance of differences by Crosscall among players in mental rigidity to their levels based on match results (high-moderate-low) for the sample under study $(n=12)$

\begin{tabular}{c|l|c|c|c}
\hline \hline No. & \multicolumn{1}{|c|}{ Variables } & Number & $\begin{array}{c}\text { Mean of } \\
\text { the ranks }\end{array}$ & $\begin{array}{c}\text { Chi } \\
\text { square }\end{array}$ \\
\hline \hline 1 & Mental rigidity for those with high marks & $\varepsilon$ & $9 . \vee 0$ & \multirow{2}{*}{7.0} \\
\hline 2 & $\begin{array}{l}\text { Mental rigidity for those with } \\
\text { moderate marks }\end{array}$ & $\varepsilon$ & 7.0. & \\
\hline 3 & Mental rigidity for those with low marks & $\varepsilon$ & r. .० & \\
\hline \hline
\end{tabular}

Table Chi square $=0.039$

It is evident through table no. (6) that there are measures of mental rigidity statistically significant differences between the three groups' under study since Chi square value was 6.5 which is significant at 0.05 . The mean 
of mental rigidity ranks for high-score players was 9.75; the mean of mental rigidity ranks for moderate-score players was 6.50; and the mean of mental rigidity ranks for low-score players was 3.25.

The researcher explains that since the high-score group has the highest mental rigidity level in the championship. They had the following positions: the first, second, third, and third bis. The moderate level of mental rigidity owned by the moderate-score group too; they had the following positions: the fifth, sixth, seventh and eighth. The low-score players had the lowest level of mental rigidity in the match results of the championship and they had the ninth, tenth, eleventh and twelfth positions. Thus, it is clear how mental rigidity is important for Sabre players as it positively affects match results, and how it is important in training or sportive competition.

The

researcher attributes this that mental rigidity helped the players to understand a skill, concentrate on technical points, seclude negative stimuli unrelated to performance and maintain quietness and the relevant stimulus, and increase positive energy which helps a player to be active. Additionally, motivation increases players' insistence 0 to achieve triumph. It also helps players to stabilize performance level in addition to attention control that contributes to the differentiation of important points than non-important ones and setting priorities according to their significance for the player during competition.

The researcher also sees that mental rigidity is one of the variables that must be cared for along with the physical, skillful and tactic requirements during training or sportive competition. Since players have different levels of mental rigidity, their levels differ as for match results.

Jimes Loehr (12) (1994) mentions that coaches and sportsmen confirm that psychological skills that reflect mental rigidity contribute with a ratios not less than $50 \%$ in the achievement of the sportive achievement.

Al-Araby Shmoan

(2001) sees that performance level is of the most important factors that must be cared for when designing psychological 
skill programs since
performance level varies
according to players'
classification in the light of
experience and the number of
practice years. This also
confirms the significance of
approximating performance
level in order for achieving the
desired interaction.

\section{Conclusions and Suggestions}

Conclusions

1- The participation ratio of the whole mental rigidity in match results was 0.98 . There are participation ratios of mental rigidity dimensions individually, but they are nonsignificant (ineffective) in match results in the national championship for Sabre players under 13 years.

1-The relative weight of mental rigidity dimensions as a whole for Sabre players under 13 years in the national championship was $90.00 \%$, which is a strong level. Positive energy dimension ranked first of all dimensions since it was strongly achieved; negative energy dimension ranked last of all dimensions since it was strongly achieved. 2-There is a positive correlation between mental rigidity and match results in the national championship under 13 years.

3-There are statistically significant differences in match results between the three groups (high scorers-moderate scorers-low scorers) and mental rigidity, where the highest level of mental rigidity was of the high-score group. Whereas the moderate-score group had the moderate level of mental rigidity, the lowscore group had the lowest level of mental rigidity in the match results of the national championship for Sabre players under 13 years.

\section{Recommendations}

In the light of the research results, and based on what the research came about with, the researcher presents the following recommendations:

1-The necessity of coaches being interested in improving Sabre players' mental rigidity level for its effective role in improving match results right from the training process.

2-The necessity of directing Sabreplay coaches' attention to shed light on psychological attributes of mental rigidity as a whole and not sticking to one attribute while ignoring the other during the training process. 
3-The necessity of Sabreplay coaches being interested in preparing programs specified to mental rigidity along with the training program in the stages of physical, skillful and tactic preparation during competition.

4-Conducting such a study on Sabre players and fencing and on some individual or group sports.

The list of references:

First: References in Arabic:

1. Ibrahim Nabil Abdul Aziz: the technical foundations for fencing, i2, Book Publishing Center, Cairo، (2005).

\section{2- Osama Abdul Rahman;}

"The effect of the difference in the training medium on the effectiveness of the performance of the movements of the two men to duel,"PhD thesis, unpublished, Faculty of Physical Education, Alexandria University, (1999)

\section{3- Osama Abdul Rahman:} basic principles in the duel, printing house, Alexandria (2003).

4- Osama Rateb: The motives of excellence in sports activity, Arab Thought House, Cairo (1990)

5- Osama Rateb: Psychological preparation for the training of youth, a guide for trainers and parents, Dar al-Fikr Arab, Cairo (1997)

6- Osama Rateb: Training of psychological skills applications in the field of sports, Arab Thought House, Cairo (2001)

\section{7- hussein pilgrims and ramzi}

el tanbolee: fencing science and art, printing and publishing, the conquest of Alexandria (2No. 98/2007)

\section{8- Mohamed Shamoan:}

Mental Training in Sports Field, 2nd Floor, Dar Al Ma'aref, Cairo (2001)

9- Mohamed Shamoan \& Magda Ismail : Guidance and psychological guidance in the field of sports, Arab Thought House, Cairo (2002)

Second: Foreign References:

- Chris Sellars :Building selfconfidence, coachwise puplish. England, 1997. 10

11- Gould, D., Dieffenbach, K., \& Moffett, A: Psychological characteristics and their development in olympic champion journal of applied sport psychology, 17, 2002.

12- James loehr: the new toughness training for sports new york, penguin Books, U.S.A, 1994.

13- John Lefkowits, David R.

Mc Duff, Corina Riismandel: 
Mental toughness training manual for soccer, United Kingdom: Article Sports Dynamics, 2003.

14- Jolly Ray: Mental toughness, Level III Hockey coadhing course Karnataka stat Hochey Association, Bangalors, 003.

15- Keith Pritchard: Goal Setting and Soccer Performance, A.S.A, senior provinicial coach, U.S.A, 2002. 16- Psychological Characterictics of Male Jymnasts Differevces
Petween Competitive Levels, J.S Portes, S.C.I, 8 (2).

17- Simon C. Middleton, Herb W. Marsh, Andrew J. Martin, Garry E. Richards and clark perry : Discovering Mental toughness: A Qualitative study of Mental toughness elite athletes, third international biennial, self research conference, selfconcept, Motivation and identity: where to form here, july 4-7, Berlin, Germany, 200 